\title{
TAFSIR FIKIH DALAM KHAZANAH PENAFSIRAN ALQURAN
}

\author{
Arif Zunzul Maizal
}

Institut Agama Islam Negeri Batusangkar

e-mail: arif.zm@iainbatusangkar.ac.id

\begin{tabular}{|l|l|l|}
\hline Diterima: 18-09-2019 & Direvisi: 03-10-2019 & Dipublish: 29-06-2020 \\
\hline
\end{tabular}

Abstract: The interpretation of the Koran as a sacred text turns out to not escape subjectivity. This can be seen from the rapid development of interpretation which is influenced by the subjectivity or tendency of each mufassir. Jurisprudence between trends or patterns of interpretation is growing rapidly, so it requires in-depth discussion and study. Discussion about the nature of figh interpretation is done through library research on figh interpretation works, beginning with collecting related references then discussing with using descriptive, analytical and comparative methods. From these discussions, several conclusions were formulated. First; the attention of scholars to the interpretation of fiqh is very large, this is evident in the many books of fiqh interpretations, both in the form of interpretations of fiqh verses in a special way, interpretation of fiqh verses in a thematic manner and interpretation of figh verses together with other verses in one interpretation book. Second, the method of istinbath fiqh law greatly influences the method of figh interpretation, so that differences in fiqh interpretation follow the polarization of figh schools. Third, some jurisprudents of figh interpretation are trapped by the tendency of the school they follow so that fiqh interpretation becomes a justification tool for the existing fiqh opinion concept.

Kata kunci: tafsir, mufassir, ayat, hukum dan fikih.

\section{PENDAHULUAN}

$\mathcal{A}$ lquran merupakan kitab pedoman dalamnya, Allah menjelaskan setiap permasalahan, sebagaimana firmanNya:

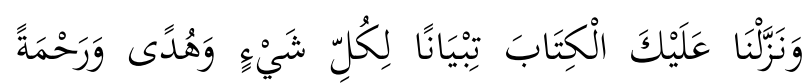<smiles>[As]=[As][As]=[W]</smiles>

"Dan Kami turunkan Alquran kepadamu (Muhammad) untuk menjelaskan segala sesuatu, sebagai petunjuk, rahmat dan kabar gembira bagi orang-orang muslim. (QS alNahl [16]: 89)

Dalam ayat lain, Allah SWT juga menegaskan bahwa tak satu pun permasalahan yang dilewatkan atau ditinggalkan penjelasnnya dalam Alquran, sebagaimana firmanNya:

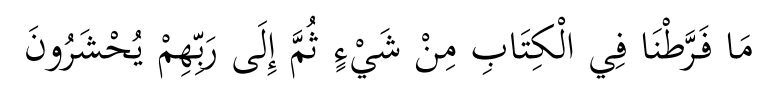

"Tidak satupun yang kami alpakan (penjelasnnya) dalam Alquran, kemudian kepada Allah mareka akan dikumpulkan". (QS. al-An'am [6]: 38)

Kesempurnaan Alquran tentang tuntunan dan pedoman kehidupan mendorong para ulama berusaha memahaminya, sehingga tuntunan dan "pedoman langit" tersebut dapat diaplikasikan di muka bumi. Upaya dalam memahami wahyu tersebut melahirkan sebuah disiplin ilmu yang disebut dengan tafsir. 
Sebagai hasil pemahaman terhadap wahyu, penafsiran Alquran tidak terlepas dari latar belakang atau bahkan subyektivitas para mufassir. Hal ini terbukti dengan munculnya berbagai corak atau kecendrungan dalam penafsiran Alquran. Mufassir yang memiliki latar belakang bahasa melahirkan tafsir lughawiy, mufassir berlatarbelakang filsafat melahirkan produk tafsir falsafiy, mufassir yang memiliki latar belakang science melahirkan tafsir ilmiy. Corak atau kecendrungan penafsiran Alquran juga dipengaruhi perbedaan mazhab baik di bidang teologi maupun fikih. Perbedaan mazhab teologi melahirkan corak tafsir kalamiy atau 'aqaidy, sedangkan perbedaan mazhab fikih melahirkan berbagai tafsir dengan corak fighiy atau tafsir fikih. (Shihab, 1993:72) Di abad modern juga muncul corak tafsir hida'i, yaitu corak tafsir yang mengutamakan pembahasan bimbingan Alquran untuk kehidupan sesuai dengan kriteria dan syaratsyaratnya. (Sulthan Abdullah Mathlaq Al'Azimiy, 2018: 296)

Di antara corak tafsir yang banyak berkembang dalam khazanah penafsiran Alquran adalah tafsir fikih. Perkembangan tafsir ini lebih pesat dibandingkan tasfir lain disebabkan banyaknya ayat Alquran yang berbicara tentang hukum fikih. Menurut Al-Gazali ayat yang membahas tentang hukum fikih berjumlah lebih kurang lima ratus ayat. Sedangkan menurut Ibn al-'Arabiy jumlahnya mencapai sekitar delapan ratus ayat. Menurut mayoritas ulama jumlahnya bisa mencapai ribuan apabila yang dimaksud dengan ayat-ayat fikih tidak hanya ayat yang secara langsung membahas fikih, tetapi juga setiap ayat yang darinya bisa di-istinbath-kan hukum fikih, seperti ayat kisah dan lain-lain. (AlIshfahaniy, 2011: 359)

Pesatnya perkembangan tafsir fikih dalam khazanah penafsiran Alquran mendorong penulis untuk meneiliti dan membahas tafsir ini untuk mendeskripsikan tentang makna tafsir fikih, sejarah perkembangan, metode dan karateristrik serta kitab dan para mufassir yang berkecimpung di dalamnya.

\section{METODE PENELITIAN}

Penelitian ini merupakan penelitian kepustakaan (library research). Sebagai langkah awal, penulis menghimpun referensi yang membahas teori penafsiran Alquran secara umum, dan tafsir fikih secara khusus, baik dalam bentuk buku, jurnal maupun referensi yang bersifat online. Penulis juga melengkapi sumber dengan kitab-kitab tafsir yang termasuk dalam kategori tafsir fikih. Dalam membahas, penulis menggunakan metode deskriptif, analitis dan komparatif. Berdasarkan referensi yang ada, penulis menggambarkan objek permasalahan, malakukan analisa secara kritis, serta membandingkan pendapat, toeri-teori dengan kondisi objektif.

\section{PENGERTIAN TAFSIR FIKIH}

Tafsir menurut bahasa al-idhah wa albayan, (penjelasan). Menurut istilah, dalam kitab al-Burhan fi 'Ulum Alquran, Imam al-Zarkasyi menjelaskan tafsir adalah:

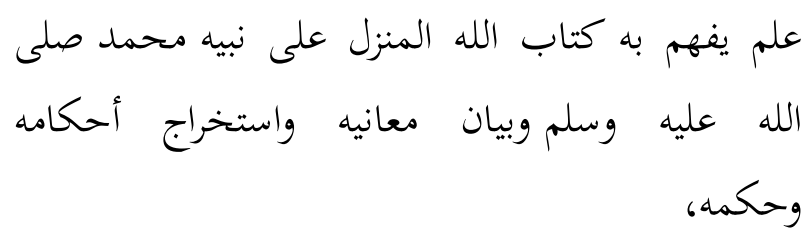


"Ilmu untuk memahami Alquran, menjelaskan makna, serta menggali hukum dan hikmah yang terkandung di dalamnya". (AlZarkasyi, 2006: 22)

Fikih seacara bahasa adalah al-fahm wa al-ilmu (pemahaman dan pengetahuan). Secara istilah fikih adalah:
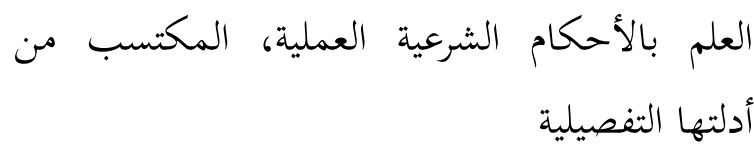

"Ilmu tentang hukum-hukum yang syar'i 'amaliy (yang terkait dengan amal perbuatan manusia) yang disimpulkan dari dalil-dalil yang rinci". (Khalaf, 1978: 11)

Tafsir dan fikih merupakan dua disiplin ilmu yang penting dalam Islam dan keduanya memiliki kaitan sangat erat. Tafsir merupakan ilmu yang dijadikan sarana menggali makna dan kandungan Alquran secara umum. Sementara fikih merupakan ilmu yang mengelaborasi penafsiran Alquran, khususnya ayat-ayat fikih, menjadi produk hukum.

Ketika term tafsir dan fikih digabung menjadi satu istilah dalam ilmu tafsir, para ulama menjelaskan tafsir fikih dengan berbagai defenisi, diantaranya:

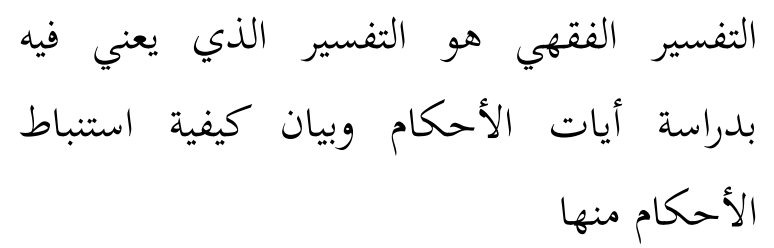

"Tafsir fikih adalah tafsir yang mengutamakan pembahasan ayat-ayat hukum dan menjelaskan cara menyimpulkan hukum dari ayat-ayat Alquran". (Bu'ikar, 2017: 15)

Yang dimaksud dengan ayat hukum adalah ayat yang menjelaskan tentang hukum agama yang terkait dengan manusia (mukallaf), seperti hukum wajib, Sunnah, mubah, makruh dan haram.

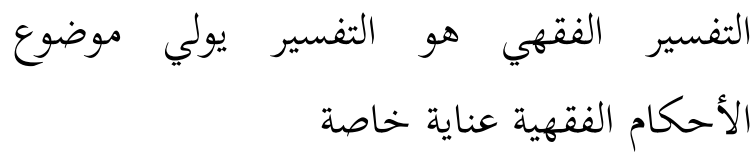

"Tafsir Fikih adalah tafsir yang membahas tema hukum-hukum fikih secara khusus". (AlSuyuthi, 1987)

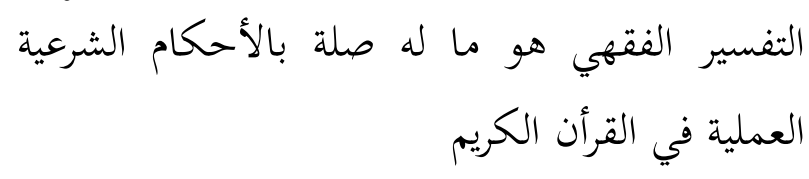

"Tafsir fikih adalah penafsiran yang berhubungan dengan hukum-hukum syar'i 'amaliy yang terdapat dalam Alquran". (Bu'ikar, 2017: 999)

Hukum syar'i 'amaliy adalah hukum agama yang terkait dengan perkataan dan perbuatan manusia, baik dalam bentuk ibadah, seperti shalat, zakat dan haji, maupun dalam bentuk mu'amalah seperti transaksi ekonomi, keluarga, kewarisan dan pidana.

Defenisi pertama mengisyaratkan bahwa tafsir fikih adalah penafsiran yang memberikan perhatian khusus atau mengutamakan penafsiran ayat-ayat hukum, meskipun mufassir tetap menafsirkan selain ayat-ayat hukum. Hal ini dapat disimpulkan dari penggunaan kata (يعني) yang dalam bahasa Indonesia berarti memperhatikan dengan sungguhsungguh. Defenisi kedua menjelaskan bahwa tafsir fikih adalah tafsir yang hanya membahas ayat-ayat hukum, dan tidak menafsirkan selain ayat hukum. Sedangkan defenisi ketiga, mendefenisikan tafsir fikih dengan ruang lingkup yang sangat luas, yaitu setiap penafsiran yang berhubungan hukumhukum syar'i.

\section{SEJARAH PERKEMBANGAN TAFSIR FIKIH}


Pada dasarnya tafsir fikih telah ada sejak turunnya ayat tentang hukumhukum fikih dan Rasulullah SAW merupakan mufassir pertama dalam tafsir ini. Rasulullah SAW telah menafsirkan ayat perintah melaksanakan shalat dengan puluhan bahkan ratusan hadis yang bersifat qauliah dan fi'liyah. Demikian juga ayat tentang zakat, puasa, haji, hudud dan masalah-masalah fikih lain dijelaskan dengan ratusan hadis yang sudah dikompilasi para ulama dalam berbagai kitab hadis.

Ketika Rasulullah wafat, para sahabat berusaha menafsirkan bahkan meng-istinbath-kan hukum dari ayat-ayat Alquran dan beramal dengannya. Dalam prakteknya, tidak jarang para sahabat berbeda pendapat dalam penafsiran dan formulasi hukum sebuah ayat. Sebagaimana perbedaan antara imam Ali ibn Abu Thalib dengan Umar ibn Khattab tentang batas minimal 'iddah wanita hamil yang suaminya meninggal. Umar ibn Khattab berpendapat bahwa masa 'iddah-nya habis dengan melahirkan, sedangkan imam Ali berpendapat iddah-nya adalah masa 'iddah yang paling lama antara 'iddah wafat (empat bulan sepuluh hari) dengan 'iddah hamil. (Al-Zahabiy, 1990: 432). Perbedaan ini terjadi adalah karena umumnya ayat yang berbicara tentang iddah thalaq (QS Thalaq [65]: 4) dengan iddah wafat (QS Albaqarah [2] :234).

Demikian juga perbedaan antara Ibn Abbas dan Zaid ibn Tsabit tentang pembagian harta warisan seorang wanita yang meninggal, dengan ahli warisnya suami, ayah dan ibu. Menurut Ibn Abbas, suami mendapat bagian setengah, untuk ibu sepertiga, sedangkan bapak sisa ('ashabah), berdasarkan firman Allah QS. an-Nisa [4]: 11. Sedangkan Zaid ibn Tsabit berpendapat bagian ayah dan ibu adalah sisa ('ashabah) dengan prinsip pembagian; "bagian untuk laki-laki dua kali bagian perempuan" berdasarkan firman Allah QS. an-Nisa'[4]:11. (Al-Zahabiy, 1990: 433)

Setelah generasi sahabat, perkembangan tafsir Alquran secara umum dan tafsir fikih secara khusus berjalan semakin pesat seiring dengan perkembangan umat Islam dan dinamika kehidupan yang mereka hadapi. Dimasa tabi'in muncullah madrasah-madrasah tafsir yang dikembangkan oleh muridmurid mufassir di kalangan sahabat. Di Mekkah muncul madrasah tafsir yang dikembangkan oleh Sa'id ibn Jubair, Mujahid, 'Ikrimah, dan 'Atha' ibn Abi Rabah yang merupakan murid-murid Ibn Abbas. Di Madinah muncul para mufassir, seperti Abu al-'Aliyah al-Riyahiy, Muhammad ibn Ka'ab al-Qarzhiy, Zaid ibn Aslam yang merupakan murid-murid Ubay ibn Ka'ab. Di Irak muncul mufassir 'Alqamah, Masruq, Hasan al-Bashriy dan Qatadah yang merupakan murid dari mufassir sahabat Abdullah Ibn as'ud. (AlQaththan, 2000: 318) Mereka semua adalah para mufassir yang sekaligus fuqaha', yang dalam penafsirannya juga menjelaskan berbagai masalah-masalah fikih.

Setelah masa itu, hadirlah para mufassir dan fuqaha' yang memberikan perhatian intensif terhadap tafsir fikih dengan melahirkan kitab yang secara spesifik membahas tentang ayat-ayat fikih. Menurut sebagian ulama, mufassir yang pertama yang menulis kitab tafsir fikih adalah Imam Syafi'i (204 H) dengan kitabnya Ahkam al-Quran. (Al-Isawiy, n.d: 27) Selanjutnya tafsir fikih semakin meluas, baik dalam bentuk lahirnya kitabkitab tafsir yang hanya membahas ayatayat fikih, yang dikenal dengan kitab Ahkam Alquran, atau tafsir fikih yang 
menjadi bagian tafsir secara umum, namun memberikan penafsiran yang lebih luas tentang ayat-ayat fikih.

Di saat munculnya era mazhabmazhab fikih, para ulama yang merupakan pengikut setia dari masingmasing mazhab melahirkan karya-karya tafsir fikih sesuai dengan mazhab yang mereka ikuti. Namun fenomena fanatisme terhadap mazhab memberikan dampak negarif terhadap perkembangan tafsir. Mufassir dari masing-masing mazhab sering berupaya "menundukkan" penafsiran Alquran dengan konsep fikih atau formulasi hukum fikih yang mereka ikuti. Seperti Abdulllah al-Karkhiy $(340 \mathrm{H})$ salah seorang mufassir yang fanatik dengan mazhab hanafiy mengatakan, "setiap ayat dan hadis yang berbeda dengan mazhab kami, maka akan ditakwilkan atau dinilai nasakh. (Al-Ishfahaniy, 2011: 361)

Demikian juga, Imam al-Suyuri dalam pengantar tafsirnya, Kanzul Irfan fi Figh Alquran, menjelaskan bahwa ia melakukan penafsiran ayat-ayat fikih secara tematik, dan akan mengungkapkannya sesuai dengan mazhab fikih Imamiah. Beliau juga membahas pendapat-pendapat fikih yang berbeda dengan mazhab Imamiah dan menjelaskan bantahan terhadapnya. (Al-Suyuriy, n.d: 17)

Dengan meredupnya fanatisme mazhab setelah abad pertengahan, tafsir fikih berkembang dengan wujud yang lebih objektif. Tafsir fikih hadir dengan membahas ayat-ayat fikih secara komparatif. Menggambarkan berbagai perbedaan pendapat ulama fikih tentang sebuah ayat, kemudian melakukan tarjih secara objektif, tanpa terikat dengan mazhab-mazhab yang telah ada. Seperti tafsir Nail al-Maram min Tafsiir Ayat alAhkam karangan Abu al-Thayyib Shadiq ibn 'aliy al-Husainiy (1307 H), tafsir Rawai' al-Bayan fi Tafsir Ayat al-Ahkam karangan Syekh Ali al-Shabuniy.

\section{METODE DAN KARAKTERISTIK TAFSIR FIKIH}

Terdapat bebera metode tafsir fikih yang diterapkan para mufassir, diantaranya adalah:

a. Tafsir fikih dengan metode penafsiran Alquran secara utuh, namun sangat rinci dalam menafsirkan ayat-ayat fikih.

Tafsir fikih dengan metode ini terlihat hampir sama dengan kitab tafsir secara umum karena membahas semua ayat Alquran dengan berbagai aspeknya, namun dalam menafsirkan ayat-ayat hukum mufassir membahasnya secara rinci. Seperti kitab tafsir Jami' al-Bayan li Ahkam Aquran karangan Imam al-Qurtubiy. Dalam tafsinya, ia berusaha membahas secara rinci masalah demi masalah hukum yang terdapat dalam sebuah ayat, sehingga dalam satu ayat dapat diuraikan menjadi belasan bahkan puluhan masalah hukum.

b. Tafsir fikih dengan metode penafsiran ayat-ayat fikih secara khusus, berurutan sesuai dengan urutan surat dalam Alquran.

Tafsir fikih dalam bentuk ini banyak dituliskan ulama dengan nama kitab Ahkam al-Quran. Setiap mazhab fikih memiliki kitab tafsir Ahkam Alquran. Dalam prakteknya, mufassir membahas ayat-ayat fikih secara berurut dalam satu surat dan tidak menafsirkan ayat-ayat selain fikih. 
Seperti Tafsir Ahkam al-Quran karangan Ibn al-'Arabiy. Dalam kitabnya, Ibn al'Arabiy tidak menafsirkan semua ayat dalam satu surat tetapi hanya memilih ayat-ayat hukum, seperti pada surat alMaidah, beliau hanya membahas 34 ayat, pada surat al-An'am membahas 18 ayat, pada surat al-A'raf membahas 27 ayat, dan pada surat al-Anfal membahas 25 ayat. (Al-'Arabiy, 2002: 4)

Mufassir juga memberikan tema fikih terhadap satu atau sekelompok ayat yang ditafsirkan. Seperti tafsir Rawa'i al-Bayan Tafsir Ayat al-Ahkam min Alquran karangan Muhammad Ali alShabuniy. Beliau memulai penafsiran QS. al-Baqarah [2]: 101 dengan tema mauqif al-syariah min al-sihr, dilanjutkan dengan ayat 106 dengan tema al-naskh $f i$ Alquran, selanjutnya ayat 142 dengan al-tawajjuh ila al-ka'bah fi al-shalah, selanjutnya ayat 158 dengan tema alsa'yu baina al-Shafa wa al-marwa, ayat 159 dengan tema Kitman al-ilmu alsyar'i, selanjutnya 172 dengan tema Ibahah al-thayibat wa tahrim al-khabais, (Al-Shabuniy, 1980: 621) dan demikian seterusnya.

c. Tafsir fikih dengan metode tematik.

Tafsir fikih tematik dilakukan dengan menghimpun ayat dari berbagai surat tentang sebuah tema fikih, seperti ayat-ayat tentang thaharah, shalat dan tema lainnya. Setelah itu masing-masing ayat ditafsirkan dan meng-istinbath-kan hukum dari ayatayat tersebut. Metode ini dipergunakan al-Miqdad al-Suyuriy dalam tafsirnya Kanzul 'Irfan fi Figh al-Quran.

Dalam muqaddimah kitabnya alMiqdad al-Suyuri mengatakan bahwa tafsir ini hanya membahas ayat hukum saja, tidak membahasnya surat per surat sesuai urutan mushaf, tetapi memilih tema di antara tema fikih seperti thaharah, kemudian mengumpulkan setiap ayat Alquran yang terkait dengan tema tersebut, dan menjelaskan setiap ayat sesuai dengan batasannya, sekaligus menjelaskan hukum yang terkandung di dalamnya sesuai dengan mazhab Imamiah Istna 'Asyariah. (AlSuyuriy, n.d: 16) Metode ini juga diikuti oleh Qathb al-Din al-Rawandi dalam kitab tafsirnya Figh al-Quran.

Di abad modern juga melahirkan tafsir fikih dengan metode tematik yang lebih sederhana, terutama tematema yang berhubungan kehidupan rumah tangga, kehidupan sosial, ekonomi dan politik. Namun tulisan tafsir fikih dalam bentuk ini tidak dihimpun dalam satu kitab tafsir, tetapi menyebar dalam bergagai buku atau majalah yang diterbitkan.

Di antara tokoh-tokohnya adalah Muhammad Abduh, Muhammad Abu Zahrah, Syeikh Syaltut, Abu A'la alMaududiy, Yusuf Musa, Musthafa AlShiba'i. Dalam berbagai karyanya, ulama tersebut menulis tentang berbagai tema fikih beradasarkan ayatayat Alquran. Tema yang sering dibahas dalam masalah keluarga adalah poligami, talak, dan kewarisan. Tema politik yang sering dikaji adalah kewajiban berhukum dengan hukum Allah, interaksi Muslim dengan Non Muslim dan persatuan umat Islam

Sebagai salah satu kecendrungan atau corak dalam penafsiran Alquran, tafsir fikih memiliki beberepa karakteristik, diantaranya:

a. Mengutamakan tafsir ayat-ayat yang mengandung hukum fikih. (AlIshfahaniy, 2011: 361)

Para mufassir fikih memberikan perhatian besar terhadap ayat yang 
berbicara tentang hukum fikih. Mufassir fikih yang menafsirkan Alquran secara utuh memberikan penafsiran yang panjang dan rinci ketika bertemu dengan ayat-ayat fikih. Seperti yang dilakukan oleh Imam Alqurthubiy dalam tafsirnya Jami' li al-Ahkam Alquran. Ketika menafsirkan surat alMaidah ayat tiga tetang makanan yang diharamkan beliau membaginya menjadi dua puluh enam sub pembahasan, atau ketika menafsirkan ayat enam yang berbicara tentang wudhu', beliau membagi pembahasan menjadi tiga puluh dua sub pembahasan.

Sedangkan bagi mufassir fikih yang tidak menafsirkan Alquran secara utuh, perhatian mereka lebih terlihat dengan menafsirkan ayat-ayat yang bernuansa fikih semata dan tidak membahas selain ayat-ayat fikih. Inilah karakteristik yang ditemukan dalam berbagai kitab Ahkam al-Quran yang ditulis para dalam berbagai mazhab.

b. Mufassir berupaya maksimal mengistinbath-kan hukum syar'i dari ayat Alquran.

Karakteristik mendasar dari tafsir fikih adalah mufassir berusaha menformulasikan hokum fikih dari ayat yang dibahas, seperti yang dilakukan oleh Muhammad Ali al-shabuniy dalam tafsirnya Rawa'i al-Bayan Tafsir Ayat al-Ahkam Min Alquran. Formulasi hukum bahkan sudah terlihat dari tema-tema yang diberikan kepada satu atau sekelompok ayat. Seperti tema Ahkam al-wudhu' wa al-tayammum terhadap ayat ke-6 surat al-Maidah, tema $t a^{\prime} a d d u d$ al-zaujat terhadap empat ayat pertama surat al-Nisa'. Dalam setiap menafsirkan ayat, setelah men- jelaskan analisa lafaz, makna secara umum, dan asbab al-nuzul, pada bagian akhir beliau menjelaskan tema al-ahkam al-syar'iyyah. Pada bagian tersebut, ia menjelaskan berbagai hukum-hukum yang dapat disimpulkan dari ayat yang sedang dibahas.

Dengan demikian, para mufassir dalam penafsirannya tidak hanya berperan sebagai mufassir, tetapi langsung memerankan diri sebagai seorang mujtahid fikih.

c. Banyak menggunakan manhaj fikih dalam penafsiran Alquran

Mayoritas mufassir fikih merupakan seorang mujtahid. Konsekwensinya, manhaj fikih dalam menganalisa dan mengambil kesimpulan banyak digunakan untuk menafsirkan Alquran, seperti manhaj fikih tentang manthuq dan mafhum, 'am dan khash, mutlaq dan muqayyad, nasikh dan mansukh, kehujjahan khabar ahad, dan metode-metode fikih lainnya.

Al-Jashshas, dalam tafsinya Ahkam Alquran menafsirkan QS. alBaqarah [2]: 232, menyimpulkan bahwa seorang gadis boleh menikah tanpa wali atau tanpa izin wali. Kesimpulan ini dipengaruhi oleh manhaj mazhab Hanafiy tentang kehujjahan hadis ahad. Demikian juga dalam penafsiran QS. Albaqarah [2]:180 tentang wasiat untuk orang tua dan karib kerabat. Sebagian mufassir fikih mengatakan bahwa tidak ada lagi wasiat bagi orang tua dan karib kerabat, karna QS. Albaqarah [2]: 180 dinilai sudah di-nasakh-kan oleh ayat-ayat waris. Sebagian mufassir tetap memboleh wasiat karena mereka tidak menganggap ayat tersebut dinasakh-kan. 
d. Perbedaan tafsir fikih sejalan dengan perbedaan metode fikih dan ushul fikih yang dipilih oleh mufassir.

Perbedaan tafsir fikih yang terdapat di dalam kitab-kitab tafsir fikih sangat dipengaruhi oleh perbedaan metode fikih yang digunakan para mufassir dalam masing-masing mazhabnya. Seperti perbedaan penafsiran terhadap firman Allah Swt Surat al-A'raf ayat 204 tentang kewajiban mendengar dan diam pada saat mendengar bacaan Alquran

Dalam menfasirkan ayat ini, mufassir berbeda dalam menyimpulkan hukum makmum membaca bacaan shalat di saat imam membaca alfatihah dan ayat. Al-Jashshash dalam tafsirnya menjelaskan bahwa makmum wajib mendegar bacaan imam dan diam, tidak membaca alfatihah dan ayat. Hal ini sejalan dengan mazhab Hanafiy yang berpendapat makmum tidak wajib membaca bacaan di belakang imam. (Najm Abdun Nashir AlMakdamiy, 2013: 153)

Imam al-Razi dalam tafsirnya menjelaskan bahwa makmum wajib membaca surat Alfatihah. Hal ini sejalan dengan mazhab Syafi'i. Beliau beralasan bahwa ayat tersebut ditakhshish oleh sabda Rasulullah SAW, "tidak sah shalat bagi orang yang tidak membaca Alfatihah. Perbedaaan ini terjadi akibat perbedaan manhaj fikih, khususnya tentang kebolehan khabar ahad dalam men-takhshish ayat yang bersifat umum.

Alhasil, apabila seorang mufassir yang juga sekaligus ahli fikih berpendapat tentang kehujjahan dalalah Alquran, khabar ahad dan ijma', maka kesimpulan penafsirannya akan berbeda dengan mufassir yang secara fikih tidak sependapat dengan kehujjahan dalalah Alquran, khabar ahad dan ijma'.

\section{KITAB DAN TOKOH TAFSIR FIKIH}

Dibanding corak tafsir lainnya, tafsir fikih memiliki banyak mufassir dan warisan kitab lebih banyak. Mufassir dan kitab tafsir fikih terbagi dalam polarisasi mazhab fikih yang berkembang, terutama pada abad pertengahan.

Di antara kitab dan tokoh tafsir fikih adalah:

a. Kitab dan mufassir di kalangan Mazhab Fikih Imamiah (Al-Ishfahaniy, 2011: 362)

1) Ahkam al-Quran, karangan alRawandi $(573 \mathrm{H})$

2) Zabdatul Bayan fi Ahkam Alquran, karangan Al-Muqaddas al-Ardabiliy $(993 \mathrm{H})$

3) Kanzul 'Irfan fi Figh al-Quran, karangan Fadhil al-Miqdad alSuyuriy

4) Tafsir Ayat al-Ahkam, karangan Sayyid Muhammad ibn Husai alTahaba' thaba'iy $(1386 \mathrm{H})$

5) Tafsir Syahiy, karangan Sayyid Amir abu al-Futuh al-Husainiy al-Jurjani $(976 \mathrm{H})$

6) Masalik al-Afham ila Ayat al-Ahkam, karangan Jawad al-Kazhimiy

b. Kitab dan mufassir di kalangan Mazhab Hanafiy

1) Ahkam Alquran karangan Abu Ja'far Ahmad ibn Muhammad alThahawiy $(321 \mathrm{H})$

2) Ahkam Alquran karangan $\mathrm{Abu}$ Husain Aliy ibn Musa ibn Yazdad Alqamiy al-Hanafiy $(305 \mathrm{H})$

3) Tafsir Al-Jashshash karangan Ahmad ibn Aliy Abu Bakar al-Jashshas alRaziy al-Hanafiy (370 H) 
4) Tahzib Ahkam Alquran karangan Jamaluddin Mahmud yang dikenal dengan nama Ibn Siraj al-Hanafiy (771 H)

c. Kitab dan mufassir di kalangan Mazhab Syafi'i

1) Ahkam al-Quran yang dinisbahkan ke Imam Syafi'i

2) Ahkam al-Quran karangan alKayaharasiy

3) Nail al-Maram fi Tafsir Ayat al-Ahkam, karangan Sayyid Muhammad Shadiq ibn Hasan

4) Ahkam al-Kitab al-Mubin karangan 'Aliy Ibn Abdullah Mahmud alSyankfakiy

5) Al-Iklil fi Istinbath al-Tanzil karangan Jalal al-Din Abu Bakar Abdul Rahman al-Sayuthiy. (Al-Isawiy, n.d: 33)

d. Kitab dan mufassir di kalangan Mazhab Malikiy

1) Ahkam Alquran karangan Muhammad ibn Abdullah ibn Abd al-Hakam $(268 \mathrm{H})$

2) Ahkam al-Quran karangan Musa ibn Abd al-Rahman abu Aswad alQaththan (306 H)

3) Ahkam Alquran karangan Muhammad ibn Ahmad ibn Abdullah ibn Bakir al-Baghdadiy $(305 \mathrm{H})$

4) Ahkam al-Quran karangan Abu Bakar Ibn 'Arabiy $(543 \mathrm{H})$

5) Al-Jami' Li Ahkam al-Quran karangan Imam al-Qurthubiy $(671 \mathrm{H})$

e. Kitab dan mufassir di kalangan Mazhab Hanbaliy

1) Ayat al-Ahkam, karangan Muhammad ibn Husain ibn Muhammad ibn al-Farra' (458 H)
2) Tafsir Ayat al-Ahkam karangan Syamsuddin Muhammad ibn Abu Bakar al-Dimasyqiy yang dikenal dengan Ibn Qayyim al-Jauziyyah

3) Ihkam al-Ra'y min Ahkam al-Ala' yang ditulis oleh Syamsuddin Muhammad ibn Abdul Rahman ibn al-Dhayi'. (Al-Ishfahaniy, 2011: 363)

Di samping itu, juga terdapat kitab tafsir fikih yang tidak terkontaminasi dengan fanatisme mazhab namun berupaya melakukan perbandingan pendapat antara ulama mazhab fikih serta mentarjih-nya. Di antaranya:

a. Nail al-Maram fi Tafsir Ayat al-Ahkam karangan Muhammad al-Shadiq Hasan Khan al-Qanujiy (1347 H)

b. Kitab Alfutuhat al-Rabbaniyah karangan Muhammad Abdul Aziz (1932 M)

c. Tafsir al- Ayat al-Ahkam karangan Muhammad Ali al-Sayis (1976 M)

d. Rawai' al-Bayan fi Tafsir al-Ayat alAhkam karangan Muhammad Ali alShabuniy.

e. Tafsir Ayat al-Ahkam karangan Manna' Khalil al-Qaththan. (Al-Isawiy, n.d:37)

\section{KESIMPULAN}

Tafsir fikih merupakan salah satu bukti besarnya perhatian ulama dalam menjelaskan kandungan Alquran, terutama berhubungan dengan hukum fikih. Besarnya perhatian harus tetap mampu menjaga objektifitas dan kejujuran ilmiah dalam menghasilkan penafsiran, sehingga Alquran tetap menjadi teks sakral untuk digali maknanya bukan menjadi justifikasi terhadap pendapat yang telah ada, seperti yang terjadi pada sebagian tafsir fikih. 
Dari khazanah tafsir fikih yang ada terlihat bahwa tafsir fikih baru membahas ayat-ayat fikih semata, tetapi belum ditemukan kitab tafsir fikih yang mampu mengelaborasi hukum fikih dari selain ayat hukum, seperti ayat-ayat kisah dalam Alquran. Di samping itu, saat ini juga sangat dibutuhkan tafsir fikih komparatif dan aplikatif. Tafsir fikih yang membanding pendapat mufassir fikih dari berbagai mazhab, kemudian melakukan pen-tarjih-an serta merumuskan kesimpulan hukum yang relevan dengan perkembangan zaman.

\section{DAFTAR PUSTAKA}

Al-'Arabiy, A. B. M. ibn A. I. (2002). Ahkam al-Quran. Beirut: Darul Kutub al-`Ilmiah.

Al-Isawiy, M. S. A. (n.d.). al-Ittijah al-Fiqhiy 'Inda al-Mufassirin wa Atsaruhu. Baghdad: Kuliah al-Imam al-A'zham.

Al-Ishfahaniy, M. A. al-R. (2011). Manahij al-Tafsir, wa Ittijahatuhu, Dirasah Muqaranah fi Manahij Tafsir Alquran. Beirut: : Markaz al-Hadharah Li Tanmiah al-Fikr al-Islamiy.

Al-Qaththan, M. (2000). Pengantar Studi Ilmu Al-Quran. Terjemahan. Aunur Rafiq El-Mazni. Jakarta: Pustaka AlKautsar.
Al-Shabuniy, M. 'Aliy. (1980). Rawa'I alBayan Tafsir Ayat al-Ahkam Min Alquran. Beirut: Makatabah al-Gazali.

Al-Suyuriy, J. al-M. ibn A. (n.d.). Kanzul 'Irfan fi Figh Alquran. Taheran: Instisyarat Murtaghawiy.

Al-Suyuthi, A.-M. (1987). Tafsir al-Jalâlayn. Beirut: Dâr al-Kuttab al-'Arabi.

Al-Zahabiy, M. H. (1990). Al-Tafsir wa alMufassirun. Kairo.

Al-Zarkasyi, B. al-D. M. ibn A. (2006). alBurhan fi Ulum Alquran. Kairo: Dar alHadis.

Bu'ikar, I. (2017). al-Tajdid fi al-Tafsir. Majallat Al-Buhuts Wa Al-Dirasat, $X X I V(1)$.

Khalaf, A. W. (1978). Ilmu Ushul Figh. Kairo: Dar al-'Ilm.

Najm Abdun Nashir Al-Makdamiy, F. I. I. (2013). Atsar Ikhtilaf al-Madaris alFiqhiyyah fi al-Tafsir. Majallat Sarra Man $R a^{\prime} a$, XXXIII(9).

Shihab, M. Q. (1993). Membumikan Alquran. Bandung: Mizan.

Sulthan Abdullah Mathlaq Al-'Azimiy, Z. A. M. al-khadhr. (2018). al-Ittijah alHida'i fi Tafsir Al-Quran al-Karim. Majallat Al-Jami'ah Li Al-Dirasah AlIslamiyah, XXVII(3). 